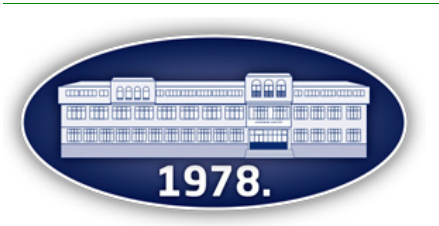

Publisher: Faculty of Agronomy Čačak

\title{
Morphometric Parameters of the Head of the Bosnian Broken-haired Hound - Barak
}

\author{
Jelena Nikitović1 ${ }^{*}$, Milivoje Urošević ${ }^{2}$ Darko Drobnjak² \\ ${ }^{1}$ Institute of Genetic Resources, University of Banja Luka, Bulevar vojvode Petra Bojovića 1a, 78000 Banja Luka, Bosnia \\ and Herzegovina \\ 2 Center for Preservation of Indigenous Breeds - CEPIB, Vere Dimitrijević 9, 11186 Belgrade - Zemun, Serbia
}

*Corresponding author: jelena.nikitovic@igr.unibl.org

Received 4 June 2021; Accepted 19 November 2021

\begin{abstract}
A B S T R A C T
Parameters of the head are among the most important characteristics of each dog breed. The first morphometric examination of hounds on the territory of Bosnia and Herzegovina was performed by Laska in 1905. Since then, no one has ever conducted morphometric measurements on the Bosnian broken-haired hound - Barak. The breed itself is recognized by the FCI, and described under standard No 155, 1973. As for the head, the standard only describes the length, with no other parameters. The aim of this paper was to determine the basic parameters of the head of the Bosnian broken-haired hound - Barak by conducting zootechnical measurements. The study involved 120 dogs, including 64 males and 56 females, aged from 9 months to 10 years, from the entire territory of Bosnia and Herzegovina. The total of five parameters of the head was measured on each dog, and four indexes were calculated based on these measurements. This paper is the first analysis of the morphometric characteristics of the head of the Bosnian broken-haired hound Barak, and the results can be used for further detailed description of this breed.
\end{abstract}

Keywords: Bosnian Barak, head, morphometric characteristics, parameter.

\section{И 3 В $О$ Д}

Параметри главе су једна од најважнијих карактеристика сваке расе паса. Прва морфометријска истраживања гонича на територији Босне и Херцеговине извршио је Ласка 1905. године. Од тада до данас нико није проводио морфометријска мјерења на Босанском оштродлаком гоничу - Бараку. Сама раса је призната од стране FCI и описана под стандардом број 155, из 1973. године. Што се тиче главе, стандард описује само дужину главе, без других параметара. Циљ овог рада је да, провођењем зоотехничких мјерења, утврди основне параметре главе Босанског оштродлаког гонича - Барака. У истраживању је учествовало 120 паса, од чега 64 мужјака и 56 женки, старости од 9 мјесеци до 10 година, са цијеле територије Босне и Херцеговине. Укупно је измјерено пет параметара главе на сваком псу, а на основу тих мјерења израчуната су четири индекса. Овај рад је прва анализа морфометријских карактеристика главе Босанског оштродлаког гонича Барака, а резултати се могу користити за даљи детаљан опис ове расе.

Кључне речи: Босански Барак, глава, морфометријске карактеристике, параметар.

\section{Introduction}

Today, we can almost certainly confirm that the domestic dog (Canis familiaris) originated from the wolf (Canis lupus). Modern canine systematization was established in 1987 at the FCI Annual Assembly in Jerusalem, when all recognized dog breeds were classified into 10 groups. According to that classification, all hounds, and thus the Bosnian brokenhaired hound Barak, were classified in the sixth group. Based on the records of ancient Greek and Roman writers, hounds inhabited the Balkan Peninsula as early as the $6^{\text {th }}$ century BC (Urošević, 2006). The Bosnian broken-haired hound Barak is recognized under FCI standard No 155 adopted on January 15, 1973. Since the Austrian Laska described the Barak in 1905, there has been no description or even mention of the Barak in the available literature. So far, no one has ever performed a morphometric analysis of the Bosnian broken-haired hound, or the data is not available. The standard for this breed was changed without proper analysis of exterior parameters.

The first morphometric examination of hounds on the territory of Bosnia and Herzegovina was performed by Laska in 1905 . His research involved 286 brokenhaired hounds, and he determined 18 exterior parameters (Laska, 1905). Based on these measurements, Laska (1905) wrote the standard for the broken-haired hound, which was the first description of the dog's exterior written in the form of a standard. The author only stated the arithmetic mean values of the measured parameters, while the intervals of variation remained unknown. Considering the parameters of the head, Laska determined that the mean value of muzzle length was $10.5 \mathrm{~cm}$, and the length of the skull $14.3 \mathrm{~cm}$. The official FCI standard for the Bosnian broken-haired hound Barak sets the length 
of the head between 20 and $25 \mathrm{~cm}$, with no specific measurements regarding males and females. The standard also describes the skull as slightly longer than the muzzle (FCI standard No 155, 1973).

\section{Materials and methods}

Zoo-technical measurements for this research were performed in order to determine five exterior parameters of the Barak's head. The research involved 120 dogs, including 64 males and 56 females, selected at random, from the entire territory of Bosnia and Herzegovina. All dogs were older than 9 months, as this age is considered in cynology to be the youngest when dogs can be assessed as adults for the measurement of exterior parameters. The oldest dog was 10 years old.

The basic morphometric parameters of the head were measured on each dog:

$$
\begin{array}{cl}
\checkmark & \text { head length, } \\
\checkmark & \text { skull length, } \\
\checkmark & \text { muzzle length, } \\
\checkmark & \text { skull width, } \\
\checkmark & \text { muzzle width. }
\end{array}
$$

The values of all measured parameters were determined using a portable scale with nonius.

The obtained results were processed using the software Statistical Package for the Social Sciences (SPSS) for Windows Release 17.0.0. The following descriptive statistic values were calculated: mean value $(\bar{x})$, standard deviation (SD), minimum value (MIN), maximum value (MAX), coefficient of variation (CV) and standard error (SE), Using the T test, statistical differences were calculated for each of the measured parameters between the sexes. Differences at $P<0.05$ were statistically significant.

The values of the parameters do not give a complete picture of the dog`s characteristics. Therefore, relative values (indexes or percentages), as ratios between certain parameters, must be calculated. It is not possible to gain a thorough insight into the dog`s condition and the breed itself without a zoo-technical analysis and index comparison (Urošević and Drobnjak, 2019). The index values were calculated using the formulas shown in table 1.

Table 1.

Calculated index values

\begin{tabular}{l|l}
\hline \multicolumn{1}{c|}{ Index } & \multicolumn{1}{c}{ Formula } \\
\hline Skull length index & Skull length / head length $\times 100$ \\
\hline Muzzle length index & Muzzle length / head length $\times 100$ \\
\hline Skull index & Skull width / skull length $\times 100$ \\
\hline Muzzle index & Muzzle width / muzzle length $\times 100$ \\
\hline
\end{tabular}

\section{Results}

The obtained results of basic morphometric

\begin{tabular}{|c|c|c|c|c|c|c|c|c|}
\hline Parameter & Sex & $\mathrm{N}$ & $\overline{\mathrm{x}} \pm \mathrm{SD}$ & Min & $\operatorname{Max}$ & $\mathrm{CV}$ & SE & $\mathrm{t}$ \\
\hline \multirow{2}{*}{ Head length $(\mathrm{cm})$} & $\hat{\sigma}$ & 64 & $23.54 \pm 1.56$ & 20.00 & 29.00 & 6.65 & 0.19 & \multirow{2}{*}{$7.209^{* * *}$} \\
\hline & q & 56 & $21.71 \pm 1.15$ & 19.00 & 24.00 & 5.34 & 0.15 & \\
\hline \multirow{2}{*}{ Skull length (cm) } & 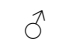 & 64 & $13.09 \pm 1.55$ & 11.00 & 17.00 & 11.88 & 0.19 & \multirow{2}{*}{$4.766^{* * *}$} \\
\hline & q & 56 & $11.85 \pm 1.24$ & 9.50 & 16.00 & 10.52 & 0.16 & \\
\hline \multirow{2}{*}{ Muzzle length $(\mathrm{cm})$} & $\hat{\sigma}$ & 64 & $10.38 \pm 0.95$ & 8.00 & 13.00 & 9.17 & 0.11 & \multirow{2}{*}{$1.436^{\mathrm{ns}}$} \\
\hline & q & 56 & $10.09 \pm 1.22$ & 7.00 & 13.00 & 12.14 & 0.16 & \\
\hline \multirow{2}{*}{ Skull width $(\mathrm{cm})$} & $\hat{\sigma}$ & 64 & $12.74 \pm 1.05$ & 10.00 & 15.00 & 8.27 & 0.13 & \multirow{2}{*}{$6.645^{* * *}$} \\
\hline & q & 56 & $11.43 \pm 1.10$ & 8.00 & 14.00 & 9.68 & 0.14 & \\
\hline \multirow{2}{*}{ Muzzle width $(\mathrm{cm})$} & $\hat{0}$ & 64 & $7.76 \pm 1.03$ & 6.00 & 11.00 & 13.33 & 0.12 & \multirow{2}{*}{$3.19^{* *}$} \\
\hline & q & 56 & $7.12 \pm 1.16$ & 4.50 & 9.00 & 16.35 & 0.15 & \\
\hline
\end{tabular}
parameters of the head of the Bosnian broken-haired hound Barak are shown in table 2 .

Table 2.

Values of descriptive statistical parameters in the examined population of Barak dogs

Head length

Head length is one of the most important exterior parameters and basic characteristics of the breed. In this study, the examined males had very homogeneous heads, with head length ranging from $20.00 \mathrm{~cm}$ to 29.00 $\mathrm{cm}$, with a variation coefficient of $6.65 \%$. Mean value was $23.54 \mathrm{~cm}$ with a standard deviation of 1.56 . It is noteworthy that both the highest and minimum value of this parameter were measured in only one dog. In all other males, head length ranged from $22.00 \mathrm{~cm}$ to $26.00 \mathrm{~cm}$.
Head length in females ranged from $19.00 \mathrm{~cm}$ to $24.00 \mathrm{~cm}$, with a mean value of $21.71 \mathrm{~cm}$. In 43 females $(76.78 \%)$ length range was between $21.00 \mathrm{~cm}$ and $23.00 \mathrm{~cm}$. Standard deviation in females was 1.15 , with a coefficient of variation of $5.34 \%$. There was a very significant statistical difference in head length between the sexes $(P<0.0001)$.

\section{Skull length}

In order to judge the harmony of head structure in dogs, it is necessary to determine values of several head parameters. One of them is skull length. A 
minimum value of $11.00 \mathrm{~cm}$ was recorded in seven male dogs (10.94\%), and a maximum value of $17.00 \mathrm{~cm}$ in only two males (3.13\%). The largest number of males, 17 of them $(26.56 \%)$, had a skull length of 12.00 $\mathrm{cm}$. The mean value of this parameter was $13.09 \mathrm{~cm}$, with a standard deviation of 1.55 . The longest skull of $16.00 \mathrm{~cm}$ in females was recorded in only one dog, while the minimum skull length of $9.50 \mathrm{~cm}$ was recorded in two females. The mean value of female's skull length was $11.85 \mathrm{~cm}$, with a standard deviation of 1.24 , and a coefficient of variation of $10.52 \%$. There was a very significant statistical difference in skull length between the sexes $(P<0.0001)$.

\section{Muzzle length}

The mean value of muzzle length in males was $10.38 \mathrm{~cm}$, with a standard deviation of 0.95 , and a coefficient of variation of $9.17 \%$. The interval of variation ranged from $8.00 \mathrm{~cm}$ to $13.00 \mathrm{~cm}$, and extreme values were measured in only one dog. Muzzle length was $11 \mathrm{~cm}$ in most dogs (20 of them, or $31.25 \%$ ), $10 \mathrm{~cm}$ in 19 dogs (26.69\%) and $10-11 \mathrm{~cm}$ in six dogs. It is obvious that the mean value was in the range between $10 \mathrm{~cm}$ and $11 \mathrm{~cm}$. In females, the interval of variation was between $7.00 \mathrm{~cm}$ and $13.00 \mathrm{~cm}$. Mean value was $10.09 \mathrm{~cm}$, with a standard deviation of 1.22 , and a coefficient of variation of $12.14 \%$. There was no statistical difference $(P>0.05)$ between the sexes for this parameter.

\section{Skull width}

Head proportions are determined by skull width. In males, this parameter ranged from $10.00 \mathrm{~cm}$ to 15.00 $\mathrm{cm}$, with a mean value of $12.74 \mathrm{~cm}$ and a standard deviation of 1.05. The maximum value was recorded in three male dogs, and the minimum in only one dog. The narrowest skull in females was $8.00 \mathrm{~cm}$, and it was found in only one dog, while the widest skull of 14.00 $\mathrm{cm}$ was found in two dogs. The mean value for this parameter was 11.43 , with a standard deviation of 1.10 , and a coefficient of variation of $9.68 \%$. There was a very significant statistical difference in skull width between males and females $(P<0.0001)$.

\section{Muzzle width}

In males, the mean value of this parameter was 7.76 , with a standard deviation of 1.03 . The minimum value of $6.00 \mathrm{~cm}$ was measured in six males, while the maximum value of $11.00 \mathrm{~cm}$ was measured in one male. In females, muzzle width ranged from 4.50 to $9.00 \mathrm{~cm}$. Mean value was $7.12 \mathrm{~cm}$, with a standard deviation of 1.16. The coefficient of variation was $13.33 \%$ in males, and $16.35 \%$ in females. There was a significant statistical difference $(P<0.001)$ between the males and females for this exterior parameter.

\section{Discussions}

Morphometric parameters of the dog's head are the most important characterization of the breed. In this study, head length in males was $23.54 \mathrm{~cm}$ on average, its range being between $20.00 \mathrm{~cm}$ and 29.00 $\mathrm{cm}$. In females, head length was in the range 19.00$24.00 \mathrm{~cm}$, i.e. $21.71 \mathrm{~cm}$ on average. Based on the obtained results in males, there were dogs that had a longer head than the standard value, while in females there were dogs that had a slightly shorter head than the standard value.
In comparison to other hounds, the Bosnian broken-haired hound Barak has a slightly longer head than the Serbian hound in Bosnia and Herzegovina in both males and females. Head length in the Serbian hound was $23.18 \mathrm{~cm}$ on average (range 21.00-25.00 $\mathrm{cm}$ ) in males, and $21.33 \mathrm{~cm}$ on average (19.50-23.00 $\mathrm{cm}$ ) in females (Nikitović et al., 2020).

Similar results were reported for the population of the Serbian hound in Serbia, with an average head length of $20.98 \mathrm{~cm}$, and the range between $19.00 \mathrm{~cm}$ and $23.00 \mathrm{~cm}$ (Pavlović and Antić, 1954). Almost identical values of head length were found in the Serbian hound 34 years later, and it averaged $20.90 \mathrm{~cm}$ (Urošević et al., 1988). In the Serbian tricolor hound in Bosnia and Herzegovina, head length in males ranged from $21.00 \mathrm{~cm}$ to $27.00 \mathrm{~cm}$, averaging $24.40 \mathrm{~cm}$, while the range in females was $20.00-23.00 \mathrm{~cm}$, with an average of $21.13 \mathrm{~cm}$ (Nikitović et al., 2020).

Compared to the Bosnian broken-haired Barak, the Bulgarian Barak has a longer head, in both males and females. The mean value of male's head length was $24.55 \mathrm{~cm}$, with a coefficient of variation of $6.47 \%$. The Bulgarian Barak females have a head length in the range of $19.00 \mathrm{~cm}$ to $25.00 \mathrm{~cm}$, with a mean value of $22.75 \mathrm{~cm}$ (Urošević et al., 2014).

Head length is always compared to height at withers. The mean value of this parameter in males of the Bosnian broken-haired hound Barak was $52.33 \mathrm{~cm}$, based on the range of $45.00 \mathrm{~cm}$ to $56.00 \mathrm{~cm}$ (Nikitović, 2020). In females, the height at withers was $48.22 \mathrm{~cm}$ on average, its range being 39.00-55.00 cm (Nikitović, 2020 ). This suggests that head length was $44-52 \%$ and $44-49 \%$ of the height at withers in males and females, respectively.

As regards the skull and its proportions, the dogs in this research have a strong and not too wide skull, as shown by the head length to width ratio. The skull of the Bosnian Barak is longer than the Serbian hound in Bosnia and Herzegovina, which was on average 12.73 $\mathrm{cm}$ (range 11.00-14.00 cm) in males, and $11.56 \mathrm{~cm}$ (range 10.00-12.50 cm) in females (Nikitović et al., 2020).

Compared to the Bosnian broken-haired Barak, the Bulgarian Barak has a wider skull, i.e. an average of $14.81 \mathrm{~cm}$ and a range of $14.00-16.00 \mathrm{~cm}$ in males, and an average of $13.63 \mathrm{~cm}$ and a range of $12.00-15.00 \mathrm{~cm}$ in females (Urošević et al., 2014).

With regard to head length parameters, the ratio of skull length to muzzle length is very important. In all breeds of hounds across morphometric studies, including our research, the skull was longer than the muzzle. Every hunting dog, including hounds, must have a strong muzzle. The muzzle length and width parameters in Barak dogs in our study showed that both males and females have a strong muzzle with a strong and well developed upper and lower jaw.

Considering the importance of head parameters and their ratios, minimum and maximum index values were calculated, in both males and females.

The skull length index: It shows the ratio of skull length to head length. A common characteristic of hound dogs is to have the skull longer than the muzzle, as in male Barak dogs. The minimum index value was 55 , while the maximum was 59. In females, this index value ranged from 50 to 67 .

The muzzle length index: This index shows the ratio of muzzle length to head length. Hounds suppose to have muzzle length shorter than skull length. The 
value of this index in males ranged from 40 to 45 , while in females it ranged from 37 to 54 .

The skull index: It shows the ratio of skull width to skull length. The analysis of the values of these parameters showed that male's skull has a rectangular to almost square shape. The minimum value of this index was 88 , while the maximum was 91 . In females, the skull has a rectangular shape, and the index value ranged from 84 to 88 .

The muzzle index: This index represents the ratio of muzzle width to muzzle length. The index value ranged from 75 to 85 in males, and from 64 to 69 in females.

\section{Conclusions}

Morphometric parameters of the head are among the most important characteristics of each dog breed. Based on the obtained results from our research, there are individual male dogs whose head is longer than the standard value, while in females, several dogs have a shorter head than the standard value.

In all examined dogs, the skull was longer than the muzzle, which is a common characteristic for hounds, though some dogs have a short muzzle, which is not a desirable feature. The index values, calculated from the measured parameters, showed that Barak dogs, both males and females, have a strong muzzle, with a welldeveloped upper and lower jaw, and a strong and too wide skull, as reflected in the head length to width ratio.

The overall comparison to other breeds showed that the Bosnian broken-haired hound Barak is larger than the Serbian hound and Serbian tricolor hound in Bosnia and Herzegovina, as well as in Serbia, but smaller than the Bulgarian Barak.

\section{Acknowledgment}

There are no contributions to either paper presentation or research to be acknowledged, since this work has been implemented solely by the author and co-authors.

\section{Declaration of competing interest}

We, the authors, hereby declare that we do not have any personal and/or financial relationships with other people or organizations that could inappropriately influence (bias, non-compliance with the academic code) our work.

\section{References}

Laska, B.F. (1905). Das Waidwerk in Bosnien und der Herzegovina, Klagenfurt.

Nikitović, J. (2020). Fenotipska i genotipska karakterizacija bosanskog oštrodlakog goniča Baraka, Doktorska disertacija, Univerzitet u Banjoj Luci, Poljoprivredni fakultet.

Nikitović, J., Drobnjak, D., Bunevski, G., Porchu, K. (2020). Basic Phenotypic Measures of Serbian Hound and Serbian Tricolour Hound Population in Bosnia and Herzegovina. Journal of Agricultural, Food and Environmental Sciences, 74(1), 56-64.

Pavlović, S., Antić, S. (1954). Balkanski gonič. Veterinarski arhiv, 24(1/2), 29-37

Standard 155. (1973). Chien courant de Bosnie a poil dur, FCI.

Statistical Package for the Social Sciences [SPSS, računarski program] (2018). IBM SPSS Software |IBM. Windows Release 17.0.0. https://www.ibm.com/analytics/spssstatistics-software

Urošević, M. (2006). Srpski i slični goniči, Kinološki savez Srbije i Crne Gore, Beograd.

Urošević, M., Drobnjak, D. (2019). Metodologija morfometrije pasa. Kinološka akademija, Beograd, ISBN: 978-86920293-3-2.

Urošević, M., Drobnjak, D., Kanev, H., Hristozov, G., Urošević, M., Ograk, Y., Matarugić, D. (2014). Morphometric Characterization of Bulgarian Barak. $3^{\text {rd }}$ International Symposium on Hunting: "Modern aspect of sustainable management of Game Populations", Zemun-Beograd, Zbornik radova, 172-177.

Urošević, M., Drobnjak, D., Kočankov, D., Ristić, Z., Fury, M., Matarugić, D. (2014). Basic Exterior Characteristics of Bulgarian scent Hound. JAFAG, 31(1), 27-31.

Urošević, M., Latinović, D., Špoljarić, B. (1988). Komparativna ispitivanja osnovnih karakteristika telesne razvijenosti balkanskog, jugoslovenskog trobojnog i jugoslovenskog planinskog goniča. Prvo jugoslovensko savetovanje o domaćim rasama goniča, Valjevo, Zbornik radova, 49-68. 